\section{Take over}

\author{
A real identity crisis.
}

\section{Jon Courtenay Grimwood}

It began when someone stole my wallet. Now, I'm not the kind of guy from whom you steal anything, and it was a good wallet - real alligator — so I was upset.

"Excuse me," he said. "I'm so sorry."

And standing up from where I'd seemingly tripped him in my hurry to get to the departures desk, he bowed. After another apology, he left in the opposite direction, still bowing.

He was foreign, obviously. Someone local would have called an attorney before even picking themselves off the floor.

At the departures desk, I put my hand inside my jacket and scowled. You know that look? The one you see in other people's eyes that says, why me? That was the look in the eyes of the boy on the other side of the desk.

"Mywallet," I said.

He waited.

I searched my other pockets, in the way that you do. Even though you know it should have been in the first pocket, and if it isn't in that pocket, then it's not going to be in any of my other pockets either.

"It's gone...."

A security guard was moving towards me before the boy even had time to suggest that I leave the queue before taking another look.

"Problems, Sir?"

“My wallet," I told him. "Someone's stolen it.

$\mathrm{He}$ did that thing security guards do where he checks your clothes and watch and shoes, and for all I know your haircut and whether you have dirt under your nails. Whatever he saw, it was enough to put some politeness back into his voice.

"When did this happen?"

"Just now," I said. "When I was on my way to the desk. A pickpocket...”

We walked to the Ops Room together, he got me a paper cup full of water and then showed me to a chair. I'd done an iris scan at the door and a computer obviously matched this to the scan I did on arrival at the airport, because I came up on the screen immediately.

“That's you, he said. It was one of those half questions.

"Yeah," I said. "That's me."

I was the broad-shouldered man pushing his way through a crowd, impervious to the scowls around me. (I've never been good in crowds. I'm a guy who likes his space.)

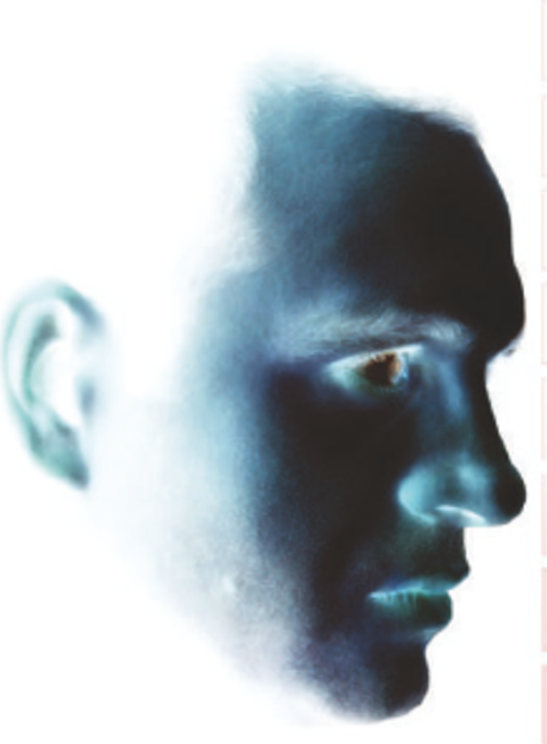

"Watch," I said.

The guard did as he was told. And he kept watching as I suddenly stumbled, looked round in a slightly drunken fashion and began talking to myself. The conversation lasted about 30 seconds, and finished with me giving an embarrassed little bow to no one in particular.

"That's impossible," I said, half rising from my seat.

"Let's take another look," said the guard. His hand on my shoulders could have been friendly. But when another two guards came into the room behind him I knew it wasn't. Actually, I'd known from the beginning.

All four of us watched the sequence.

Then we watched it again, from the moment I entered the airport to the moment it was my turn at the departures desk. A voice recorder had captured my conversation with the check-in clerk, and a box in the corner of the screen ran diagnostics. It registered $98 \%$ conviction in my voice.

"He's good," one of the guards said.

"I was robbed."

The guard shrugged towards the screen. ${ }^{\alpha}$ Doesn't look that way to me. You should have realized we'd have cameras everywhere." Glancing at the others, he raised his eyebrows.

"I've got to collect the kid," said one.

Another nodded.

"Toss him," said the guard who'd escorted me from the desk. "We can do without the grief."

Two of the guards walked to a back door, and one of them held me while the other punched me hard in the gut. He had muscles developed under full gravity. And the blow was hard enough to double me over. I'm not sure my feet even touched the three

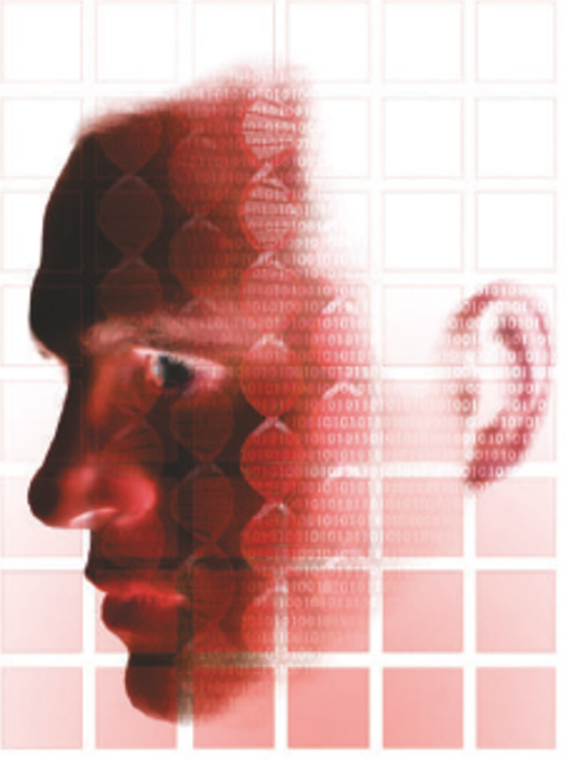

steps it took to reach the ground.

${ }^{\alpha}$ Don't come back, he said.

And that's my story... I did go back, of course. I went with a lawyer from one of those booths outside the departures lounge. He took my watch as surety and is probably still wearing it.

The guards denied ever having seen me before. As did the boy on the check-in desk, although less convincingly. They denied having punched me or shown me a replay of myself walking across the floor. And, unfortunately, the file for those few minutes had corrupted. So that was no use either.

The man living in my habitat has my ship, my bank account, my eyes, my DNA and, for all I know, my girlfriend. He seems to be doing a good job of running the corporation and I see shares are up again.

Obviously enough, he also has my wallet. From which he took all the information necessary to achieve this. So I'm waiting to go into court. Only accusing someone of identity theft is a serious matter. And the courts are not kind to vexatious accusations these days.

So, my question is, should I take the money? Should I drop my claim and sign an agreement never to repeat it? The sum I've been offered is large enough to see me out the rest of my life in relative comfort. And I won't be working 18-hour days or taking endless board meetings with people who want to replace me.

Because that's already been done. By someone so smart even my PA will probably never notice.

Jon Courtenay Grimwood is a full-time novelist. The first of his Ashraf Bey novets won the British Science Fiction Association award. His new novel is End of the World Blues (Gollancz). 